\title{
PROTEIN REQUIREMENTS OF INFANTS
}

\section{THE NUTRITION OF PREMATURE INFANTS*}

\author{
BY \\ W. F. YOUNG, M.D., D.C.H., P. POYNER-WALL, M.B., B.S., D.C.H., \\ H. C. HUMPHREYS, M.B., B.Chir., D.C.H., E. FINCH, M.SC., \\ and I. BROADBENT, M.A. \\ From the Children's Hospital and Department of Paediatrics and Child Health, \\ University of Birmingham \\ (Received for Publication, August 18, 1949)
}

During the first year of life the mortality rate is higher for prematurely born infants than for those born at term. In a recent study by Crosse and Hallum (1947) it was found that even after the first month of life, the mortality was 47 per 1,000 premature live births (twice as high as for full-term infants), infection being the main cause of death. There are no statistics for the morbidity rate, but this must also be high. Premature infants are known to become anaemic (Parsons and Hawksley, 1933; Mackay, 1935; Blackfan, Diamond, and Leister, 1944), and it seems probable that this and other effects of nutritional deficiency may contribute to the high death rate from infection. It is important therefore to supply premature babies with their full requirements for optimum nutrition and to continue to do this for some months after their discharge from hospital.

\section{Nitrogen and Protein Retention in the Foetus and Full-term Infant}

Knowledge of growth and nitrogen retention in the foetus during the later weeks of gestation may be used to outline a pattern of the needs of the premature baby. One of the most serious handicaps of premature birth is the low content of protein and of minerals in the body. Premature infants born after the twenty-eighth week are sometimes viable, but most of those who survive are born after the thirty-second week of gestation and then weigh about $1,500 \mathrm{~g}$. The development of the foetus of this age and weight whose gestation is continued to term. compared with that of the full-term infant during the first month of life is shown in Table 1. During the ninth and tenth lunar months the foetus gains about $690 \mathrm{~g}$. and 1,000 g. respectively of which

\footnotetext{
* Part of a report prepared for the Medical Research Council's
} Committee on the Protein Requirements of Infants.
100 g. and 155 g. are protein (Macy and Hunscher, 1934 ; Huggett, 1946). On a basis of bodyweight this is about $2 \cdot 0 \mathrm{~g}$. $/ \mathrm{kg}$./day, whereas the full-term infant during the first month of life retains $1.0 \mathrm{~g} . / \mathrm{kg}$./day of protein (Beach, Bernstein, and Macy, 1941), and as it grows older the amount falls to about $0.75 \mathrm{~g}$. $/ \mathrm{kg}$./day (Daniels and Hejinian, 1929; Jeans and Stearns, 1933; Nelson, '1930; Albanese, 1947). If the premature infant is to follow the pattern of growth which it would have achieved in utero, it must continue to retain as large amounts of protein as would have been laid down if gestation had been continued to term.

\section{Utilization of Protein by Prematurè and Full-term Infants}

Gordon, Levine, Wheatley, and Marples (1937) found that premature infants fed on human milk (or 'humanized' cow's milk mixtures) utilized about $70 \%$ of protein, retaining an average of $0.245 \mathrm{~g}$. of nitrogen which is equivalent to about $1.5 \mathrm{~g}$. protein $/ \mathrm{kg}$./day and represents a highly efficient use of the food. Full-term infants fed on similar diets retain less nitrogen, their utilization of protein being of the order of $50 \%$ which is equivalent to about $1 \mathrm{~g} . / \mathrm{kg}$./day (Beach et al., 1941). By raising the quantity of cows' milkand hence the protein-given to full-term infants, Nelson (1930) found that increased amounts of nitrogen were stored and that the babies gained more weight, but the maximum retention of protein was only about $1.3 \mathrm{~g} . / \mathrm{kg}$./day and not nearly as great as that which is laid down by premature babies on high protein diets. Thus nitrogen balance studies in premature infants aged 6-60 days (Gordon et al., 1937) showed that more nitrogen was retained as the protein intake was increased from about 2.8 to $5 \mathrm{~g} . / \mathrm{kg}$./day, and, with the larger amounts, 
TABLE 1

A. Gain in Weight and Protein Retention of Foetus in Last Two Months of Gestation and INfant in First Month after Birth at Term. B. Protein Requirements of Premature and Full-Term Infants Based on 'Theoretical' Needs and Utmlzation of Protein

\begin{tabular}{|c|c|c|c|c|c|}
\hline & & \multicolumn{3}{|c|}{ Foetus in Utero } & \multirow{2}{*}{$\begin{array}{c}\text { Full-Term Infant } \\
\text { First Month of } \\
\text { Life }\end{array}$} \\
\hline & - & & $\begin{array}{l}\text { Ninth Lunar } \\
\text { Month }\end{array}$ & $\begin{array}{c}\text { Tenth Lunar } \\
\text { Month }\end{array}$ & \\
\hline $\begin{array}{c}\text { A. } \\
\text { Gain in Weight (g.) }\end{array}$ & $\begin{array}{l}\text { per month } \\
\text { per day } \\
\text { per kg. body weight } \\
\text { per day }\end{array}$ & & $\begin{array}{l}\text { g. } \\
690 \\
25 \\
13 \cdot 5\end{array}$ & $\begin{array}{l}\text { g. } \\
1,000 \\
36 \\
13 \cdot 2\end{array}$ & $\begin{array}{l}\text { g. } \\
750 \\
27 \\
7 \cdot 1\end{array}$ \\
\hline Retention of Protein & $\begin{array}{l}\text { per month } \\
\text { per day } \\
\text { per kg. bodyweight } \\
\quad \text { per day }\end{array}$ & & $\begin{array}{r}100 \\
3 \cdot 6 \\
2 \cdot 0\end{array}$ & $\begin{array}{r}155 \\
5 \cdot 5 \\
2 \cdot 1\end{array}$ & $\begin{array}{r}110 \\
3 \cdot 9 \\
1 \cdot 0\end{array}$ \\
\hline $\begin{array}{l}\text { B. } \\
\text { Protein required by Infants }\end{array}$ & $\begin{array}{l}\text { per day } \\
\text { per kg. bodyweight } \\
\text { per day }\end{array}$ & & $\begin{array}{l}\text { Premature } \\
7 \cdot 2- \\
4 \cdot 0\end{array}$ & Infant & $\begin{array}{c}\text { Full-Term Infant } \\
11 \cdot 0 \\
\text { about } 2 \cdot 0\end{array}$ \\
\hline Gestational Age in Weeks & & 32 & 36 & & \\
\hline
\end{tabular}

the average retention was $0 \cdot 352 \mathrm{~g}$. nitrogen, which is equivalent to about $2 \cdot 2 \mathrm{~g}$. protein $/ \mathrm{kg}$. day, i.e. about $50 \%$ utilization. It therefore seems probable that the diet of premature infants should contain at least $4 \mathrm{~g}$. of protein $\mathrm{kg}$. day in order to allow retention of about $2.0 \mathrm{~g}$. $/ \mathrm{kg}$. day during the period corresponding to the thirty-second to fortieth weeks of gestation (see Table 1). Levine and Gordon (1942) have used 6.0 g. kg./day and it may be advantageous to give these large amounts to provide for a specific need for individual amino acids. Human milk and modified cow's milk formulae with a protein content based on that of human milk may not supply enough protein. Thus $150-180 \mathrm{ml}$., the usual volume to be well tolerated by premature infants, contain only $3 \cdot 25-2 \cdot 7 \mathrm{~g}$. of protein (assuming that the protein content of human milk is $1.5 \mathrm{~g} . \%$ ).

Relation between Diet and Weight Gain. Gordon and his co-workers have continued their studies of the nutrition of premature infants by comparing the weight gained by premature infants receiving diets which differed in composition but were of equal caloric value (Gordon, Levine, and McNamara 1947). Table 2 gives the composition of the three feeds which were used and the average weight gained by babies in two weight groups between the seventh and the twenty-eighth day of life. The difference in the amount of weight which was gained on the three feeds is significant for the smaller but not for the larger infants. Thus the 31 smaller babies receiving a high protein, low fat intake (halfskimmed milk mixture) gained an average of $17 \cdot 3 \mathrm{~g} . / \mathrm{kg}$./day and this gain is of similar magnitude to that achieved by the foetus in utero during the eighth lunar month. The 14 infants in the same weight group receiving a moderately high intake of fat and protein (evaporated cow's milk mixture), gained an average of $14.9 \mathrm{~g} . / \mathrm{kg}$./day, while the four receiving human milk (low protein and high fat) gained an average of $11.7 \mathrm{~g}$. $\mathrm{kg}$. day. In contrast the average rate of gain by the larger infants was similar for the three series receiving the different diets, and was approximately the same as that of the foetus during the ninth lunar month (Table 1). The rate at which weight was gained by both the smaller and the larger infants on all three diets, however, was high as judged by some textbook standards. This was probably due to the maintenance of a uniform caloric intake (120 cals./kg./day) which was achieved by giving feeds by gavage to infants who could not suck. The good progress of the smaller infants who were given the halfskimmed milk mixture led Gordon and his colleague to give it to a group of 11 very small infants, whose birthweights lay below $1,000 \mathrm{~g}$. Their average gain between the seventh and twenty-eighth day of life was $17.6 \mathrm{~g}$. $/ \mathrm{kg}$. day and it is probable from the data in the report that they reached an average of $2,350 \mathrm{~g}$. (a gain of $1,400 \mathrm{~g}$.) by the end of nine weeks. 
TABLE 2

Response to Different Diets in Study of Nutrition of Premature Infants (Gordon et al., 1947)

\begin{tabular}{|c|c|c|c|c|c|c|c|}
\hline \multirow[b]{2}{*}{ Type of Food } & \multicolumn{5}{|c|}{ Intake/Kg./Day } & \multicolumn{2}{|c|}{ Average Weight Gain (G./Kg./Day) } \\
\hline & $\begin{array}{l}\text { Fluid } \\
\text { (ml.) }\end{array}$ & Cals. & $\begin{array}{l}\text { Protein } \\
\text { (g.) }\end{array}$ & $\begin{array}{l}\text { Fat } \\
\text { (g.) }\end{array}$ & $\begin{array}{c}\text { Carbo- } \\
\text { hydrate } \\
\text { (g.) }\end{array}$ & $\begin{array}{c}\text { Birth weight } \\
(1,022 \text { g.-1,621 g. })\end{array}$ & $\begin{array}{c}\text { Birth weight } \\
(1,622 \mathrm{~g} \cdot-1,996 \mathrm{~g} .)\end{array}$ \\
\hline $\begin{array}{l}\text { Half-skimmed milk with added } \\
\text { carbohydrate }\end{array}$ & 150 & 120 & $6 \cdot 0$ & $2 \cdot 2$ & $19 \cdot 4$ & $17 \cdot 3$ (31 infants) & $14 \cdot 2$ (36 infants) \\
\hline Evaporated cows' milk & 150 & 120 & $4 \cdot 8$ & $5 \cdot 5$ & $12 \cdot 9$ & $14 \cdot 9$ (14 infants) & $13 \cdot 7$ ( 25 infants) \\
\hline Human milk & 180 & 120 & $2 \cdot 2$ & $6 \cdot 7$ & $12 \cdot 9$ & $11 \cdot 7$ (4 infants) & $12 \cdot 7$ (12 infants) \\
\hline
\end{tabular}

The rate of gain was therefore equal to that of the foetus during the later weeks of gestation.

Few paediatricians expect progress of the order which has just been described from very small premature infants during the early weeks of life. Hess and Lundeen (1941), for instance, consider that a daily weight gain of 5 to $10 \mathrm{~g}$. is adequate for infants weighing less than $1,500 \mathrm{~g}$. and believe that ' minimal feedings' are rewarded by good ultimate results. The premature infants under their care usually receive only 80 and never more than 100 calories $/ \mathrm{kg}$./day until they are one month old. The food is a mixture of three parts human milk and one part buttermilk in amounts which supply only 2-3 g. protein-kg./day, but water is given to raise the fluid intake to $160 \mathrm{ml} . / \mathrm{kg}$./day. Jorpes, Magnusson, and Wretlind (1946), using human milk alone in amounts to supply $100 \mathrm{cals}$. $/ \mathrm{kg}$./day for feeding premature infants, also found that their patients gained weight slowly. Recently, these authors have supplemented human milk with a preparation of hydrolysed casein (' aminosol '), and infants receiving this diet have gained weight much more rapidly. Hydrolysed casein was found to be more effective than raw casein when the supplement given was $2 \cdot 5 \mathrm{~g} . / \mathrm{kg}$./day. Jorpes et al. (1946) now use human milk supplemented with ' aminosol ' and glucose $(2.5 \mathrm{~g} . / \mathrm{kg}$./day of each) and have recorded that when this diet, in amounts to provide 120 cals./kg./day, was given to seven infants whose average birth weight was $1,354 \mathrm{~g}$., an average gain of $654 \mathrm{~g}$. was achieved during the first month of life. This compares well with the 510 and $690 \mathrm{~g}$. gained by the foetus in utero during the eighth and ninth lunar months. A group of nine infants with an average birthweight of 1,962 g. gained $561 \mathrm{~g}$., which does not compare so well with the $840 \mathrm{~g}$. laid down by the foetus in utero during the later part of the ninth and early part of the tenth lunar months. Nevertheless, the weight gained by both groups of infants was nearly twice as great as that gained by the babies of similar birth weights who were given human milk alone in quantities to supply 100 cals./ kg./day. Since it has been shown that premature infants receiving adequate diets will gain weight at a similar rate to the foetus in utero at corresponding weeks of gestation, it seems evident that this rate should be used as the standard in assessing the progress of these babies.

Our investigation was part of a trial which was planned by a committee appointed by the Medical Research Council. At the time when Magnusson (1944 and 1945) and Jorpes et al. (1946) reported the value of 'aminosol' for feeding premature infants were published, British preparations of hydrolysed casein had recently become available. It seemed rational to use predigested protein to supplement the protein intake of premature babies since, first, they have low gastric acidity (Miller, 1941) and the enzymic activity in the stomach, pancreas, and possibly the bowel is underdeveloped (Werner, 1948), and secondly they tend to vomit and to aspirate after feeding. Protein digests are composed of a mixture of polypeptides and amino acids which is freely soluble and can be absorbed by the alimentary tract without much digestive activity, and no curd is formed in the stomach. The present trial of hydrolysed casein was begun before the paper by Gordon et al. (1947) showing the value of half-skimmed milk mixtures for feeding young premature babies had been published, although Levine and Gordon (1942) had presented a preliminary report. The relative merits of predigested and whole milk protein have yet to be fully investigated.

\section{Present Investigation}

Grouping. All infants admitted to hospital were examined on the third day of life in order to assess their general condition, and any infant whose 
condition was very poor or who had a congenital malformation was omitted from the investigation. The remainder were grouped according to their birth weight into the half-pound weight groups which are shown in Table 3.

TABLE 3

Grouping of Premature Infants according to BIRTH WEIGHT

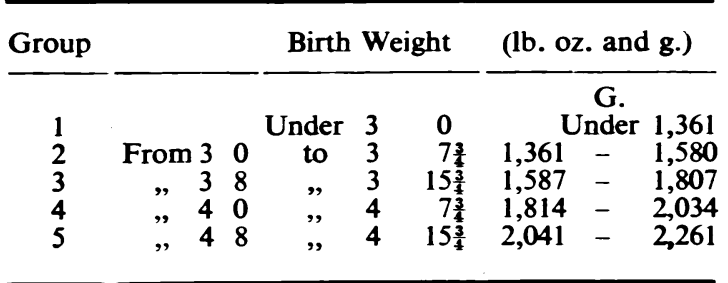

Feeds. In planning the investigation it was arranged that the diets which were already being used should be continued as a basis for the feeds to be given. An amount of casein hydrolysate to raise the protein concentration by about $2 \mathrm{~g} . / 100 \mathrm{ml}$. was to be added to the milk feeds of alternate infants, while control cases were to be given similar milk feeds which contained a $2 \%$ sugar supplement instead of the hydrolysate. Thus both groups were to receive diets of equal caloric value.

The composition of the milk feeds which were used at the beginning (Period I) of our investigation is shown in Tables 4 and 5 . After the investigation had been in progress for nine months (January to October, 1946), it became apparent that the infants were not gaining as much weight during the first month of life as had been gained by infants who had been given the optimum diet used by Jorpes $e t$ al. (1946). The caloric intake of the babies in our series was lower during the first weeks of life, and this was thought to explain their lower weight gains. It was therefore decided to use feeds of higher caloric value by giving both the casein hydrolysate and the sugar supplement together in the milk mixtures which were being used. The composition of these feeds, which were used in the later part of our investigation (Period II), is shown in Tables 4 and 5 (see over). Evaporated and dried milk of known percentage composition was used, the same brands* being given to the infants throughout the investigation. Human milk was obtained locally and was not analysed. Two preparations of casein hydrolysate were supplied for the investigation, one by Ashe Laboratories Ltd. and the other by Genatosan Ltd. They contained similar amounts of protein but there were differences in the mineral composition (see Table 6), the most important being the lower

- Regal brand (Wilts United Dairies) full cream and half cream (Special), Cow and Gate.'
TABLF 6

Comparison of Mineral Content of 'Ashe' ANd 'Genatosan' Casein Hydrolysate

Casein Hydrolysate

\begin{tabular}{cccc} 
& $\begin{array}{c}\text { 'Ashe } \\
\text { (mg. 10 g. } \\
\text { hydrolysate) }\end{array}$ & $\begin{array}{c}\text { Genatosan } \\
\text { (mg. 10 g. } \\
\text { hydrolysate) }\end{array}$ \\
\hline Total calcium (Ca.) & $17-34$ & 134 \\
, sodium (Na.) & $12-23$ & 15 \\
,, potassium (K.) & $\begin{array}{c}\text { Trace } \\
\text {," chlorine (Cl.) }\end{array}$ & $11-40$ & 40 \\
," phosphorus (P.) & $1-34$ & 24 \\
\hline
\end{tabular}

calcium content of the Ashe product. Fortunately, the change from 'Ashe' to 'Genatosan' hydrolysate was made at a time when the plan of the Birmingham investigation was being altered, and therefore the results could easily be separated. The 'Ashe' hydrolysate was used throughout the first period except for a week or two at the end when the supplies were exhausted, while 'Genatosan' was used throughout the second period.

PERIOD I. The plan was to give alternate infants in each weight group the protein supplemented feeds and the control feeds (Tables 4 and 5). A $5 \%$ glucose solution was to be given during the first 48 to 72 hours of life until milk feeds were begun. The infants were then to be given the control feeds until their daily fluid intake had reached $120 \mathrm{ml}$. $\mathrm{kg}$. ( $2 \mathrm{oz}$. lb.), aiming to give this volume by the end of the first week. After this, the protein-supplemented feed was to be introduced for those infants who had been scheduled to receive it. The feeds were to be graded through the Stages 1 and 2 shown in Table 5, and the stronger Stage 3 feeds (Table 4) were usually to be given between the second and third week of life, depending upon the size and condition of the infant. Most of the smaller infants received the milk mixtures during the early weeks of life according to the plan. A few of the bigger (over $4 \mathrm{lb}$.) infants were fed from the breast. and many of them were given the full-cream dried milk mixture (1 in 16) from the start so that as soon as they were considered fit they could be sent home on an easily prepared diet. The percentage composition of this dried milk mixture is similar to that of the evaporated milk control feed. All the babies were given the dried milk mixture before their discharge from hospital, and the strength was subsequently increased from 1 in 16 to 1 in 12 .

PERIOD II. The plan was to give all the infants the high protein and high calorie diets as soon as milk feeds were introduced on the second or third day of life and to grade the feeds through Stages 1 and 2 (Table 5) to full-strength (Table 4). It was decided to omit many of the infants who weighed over $4 \mathrm{lb}$. at birth from this part of the investigation so that a more detailed study of the smaller 
PROTEIN REQUIREMENTS OF INFANTS

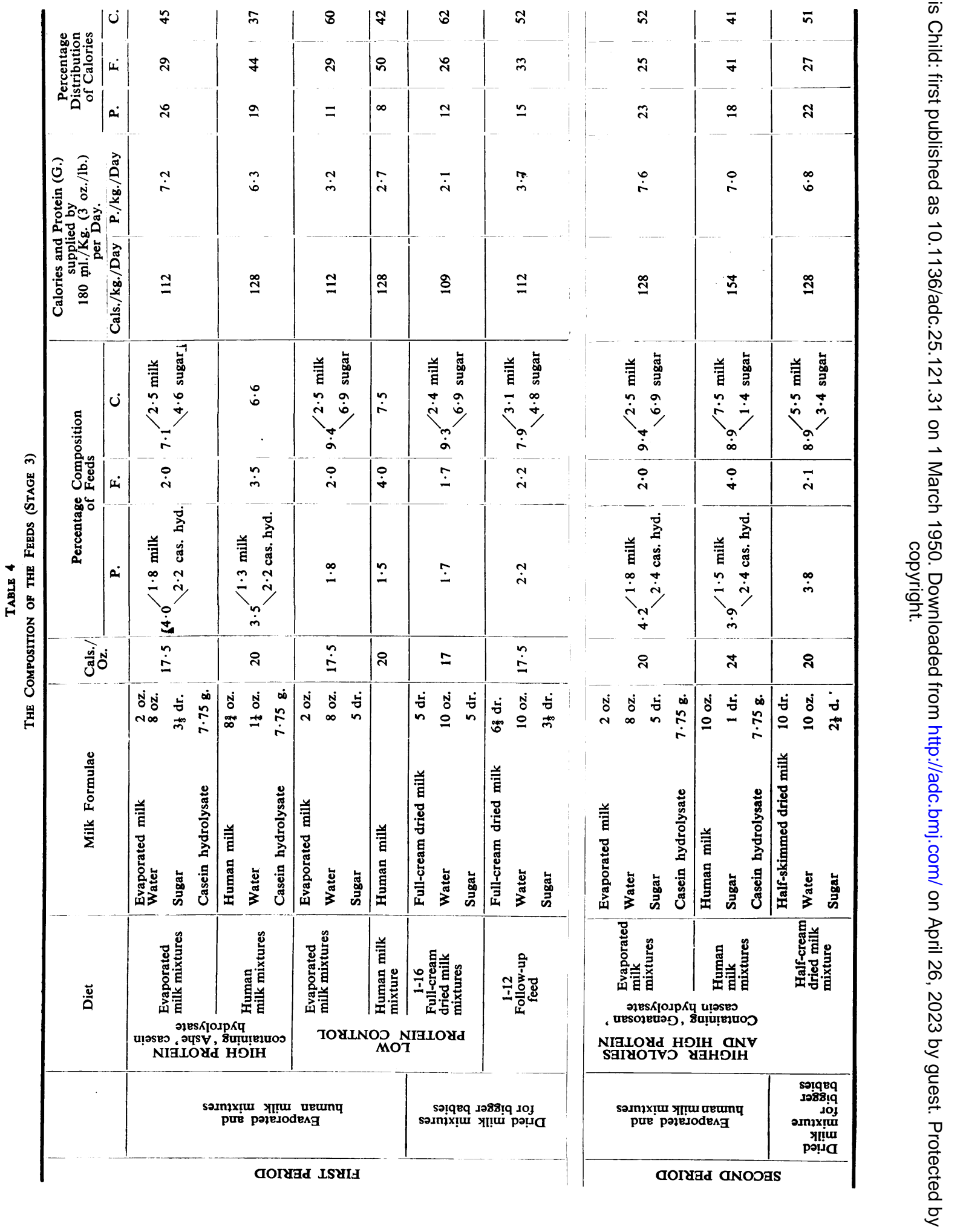


TABLE 5

The Compostion of the Evaporated and Human Mink Mixtures (Stages 1 and 2)

\begin{tabular}{|c|c|c|c|c|c|c|c|c|c|c|c|c|}
\hline & \multirow{3}{*}{\multicolumn{2}{|c|}{ Diets }} & \multirow{2}{*}{\multicolumn{2}{|c|}{ Cals./Oz. }} & \multicolumn{6}{|c|}{$\begin{array}{c}\text { Percentage Composition } \\
\text { of Feeds : } \\
\text { Stages } 1 \text { and } 2\end{array}$} & \multirow{3}{*}{\multicolumn{2}{|c|}{$\begin{array}{l}\text { Calories and Protein (g.) } \\
\text { supplied by } \\
120-180 \mathrm{ml} . / \mathrm{kg} \text {. } \\
(2-3 \mathrm{oz} . / \mathrm{lb} .) \text { per day } \\
\text { Stage } 2 \text { Feeds }\end{array}$}} \\
\hline & & & & & \multicolumn{2}{|c|}{ P. } & \multicolumn{2}{|c|}{ F. } & \multicolumn{2}{|c|}{ C. } & & \\
\hline & & & \multicolumn{2}{|c|}{ Stage } & \multicolumn{2}{|c|}{ Stage } & \multicolumn{2}{|c|}{ Stage } & \multicolumn{2}{|c|}{ Stage } & & \\
\hline \multirow{4}{*}{ 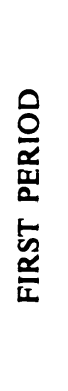 } & \multirow{2}{*}{ 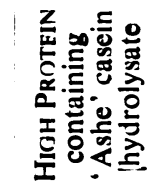 } & $\begin{array}{l}\text { Evaporated } \\
\text { milk mixtures }\end{array}$ & 8 & $14 \cdot 5$ & 1.9 & $3 \cdot 4$ & $0 \cdot 8$ & $1 \cdot 3$ & $3 \cdot 4$ & $6 \cdot 7$ & $62-93$ & $4 \cdot 1-6 \cdot 1$ \\
\hline & & $\begin{array}{l}\text { Human } \\
\text { milk mixtures }\end{array}$ & 12 & 17 & $1 \cdot 7$ & $3 \cdot 2$ & $1 \cdot 3$ & $2 \cdot 8$ & $5 \cdot 5$ & $6 \cdot 7$ & $73-100$ & $3 \cdot 8-5 \cdot 7$ \\
\hline & \multirow{2}{*}{ 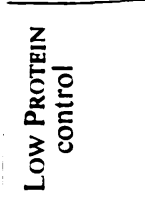 } & $\begin{array}{l}\text { Evaporated } \\
\text { milk mixtures }\end{array}$ & 9 & $14 \cdot 5$ & $0 \cdot 8$ & $1 \cdot 2$ & $0 \cdot 8$ & $1 \cdot 3$ & $5 \cdot 7$ & $9 \cdot 0$ & $62-93$ & $1 \cdot 4-2 \cdot 2$ \\
\hline & & $\begin{array}{l}\text { Human } \\
\text { milk mixtures }\end{array}$ & 10 & 15 & $0 \cdot 8$ & $1 \cdot 1$ & $2 \cdot 0$ & $3 \cdot 0$ & $3 \cdot 8$ & $6 \cdot 6$ & $64-96$ & $1 \cdot 3-2 \cdot 0$ \\
\hline \multirow{2}{*}{ 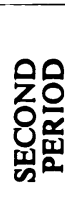 } & 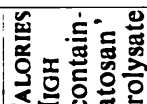 & $\begin{array}{l}\text { Evaporated } \\
\text { milk mixtures }\end{array}$ & $10 \cdot 5$ & 17 & $2 \cdot 0$ & $3 \cdot 6$ & 0.8 & $1 \cdot 3$ & $5 \cdot 7$ & $9 \cdot 0$ & $73-109$ & $4 \cdot 3-6 \cdot 5$ \\
\hline & 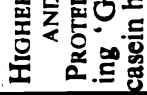 & $\begin{array}{l}\text { Human } \\
\text { milk mixtures }\end{array}$ & 17 & 21 & $1 \cdot 9$ & $3 \cdot 6$ & $1 \cdot 6$ & $2 \cdot 5$ & 6.9 & $9 \cdot 1$ & 90-135 & $4 \cdot 3-6 \cdot 5$ \\
\hline
\end{tabular}

premature babies could be made. With the exception of three who were breastfed, the infants all received the higher calorie and high protein diets. Some of those weighing over $4 \mathrm{lb}$. at birth were given the half-skimmed milk mixture from the start, but its percentage composition was similar to that of the evaporated milk mixture containing casein hydrolysate. All the babies were given the dried milk mixture before their discharge from hospital. They were usually changed on to a full-cream dried milk mixture as soon as they weighed $8 \mathrm{lb}$.

Vitamin and Iron Supplements. The infants in hospital were given vitamin and iron supplements as follows:

Vitamins

Ascorbic acid $50-100 \mathrm{mg}$. daily from three days of age.

- Tab. benerva co.' $\begin{array}{lr}\text { Aneurin } & 1 \mathrm{mg} \text { Riboflavine } \\ \text { Nicotinic acid amide } 15 \mathrm{mg} .\end{array}$ $\frac{1}{2}-1$ tab. daily from three days of age.

$A$ and $D$ concentrates, "adexolin' or "radiostoleum,

$\left.\begin{array}{r}12,000 \text { I.U. vit. A } \\ \text { 3,000 I.U. vit. D }\end{array}\right\}$ daily from two weeks of age.
Iron

Mist. ferrous sulph. containing ferrous sulph. (crystalline) $5 \mathrm{gr}$. to $1 \mathrm{dr}$., small doses daily from six weeks of age, increasing to $1 \mathrm{dr}$. (Period I).

Mist. ferri et ammon. cit. containing ferri et ammon. cit. 5 gr. to $1 \mathrm{dr}$., small doses daily from two weeks of age increasing to $1 \mathrm{dr}$. (Period II).

After discharge from hospital, orange juice was gradually substituted for the ascorbic acid, and codliver oil for the fat-soluble vitamin concentrate.

Reconds and Follow-up Care. Full clinical records were kept of the progress of the infants throughout their stay in hospital, and these were continued at special follow-up clinics. Return visits at twoweekly intervals until three months, monthly until six months, and then at nine months and one year of age, were requested. Unfortunately attendances were often irregular. The patients were weighed twice weekly while in hospital and subsequently at the follow-up clinics. Advice about diet and about vitamin and iron supplements was given at the return visits, and the infants were usually allowed to start on a mixed diet at four to six months of age.

Samples of blood for serum protein and haemoglobin estimations were usually taken from the 
infants in the ward at two-weekly intervals during the first part, and at weekly intervals during the second part of the investigation. Further samples were obtained at the follow-up clinic. Satisfactory samples were not always secured and therefore the number of results from individual infants has varied.

Methods of Analysis. Haemoglobin was estimated in the Evelyn photoelectric colorimeter against a standard curve based on Van Slyke's oxygen capacity determination using the commonly accepted value of $1.34 \mathrm{ml}$. of oxygen $/ \mathrm{g}$. Hb. $(100 \%=13 \cdot 8 \mathrm{~g}$. haemoglobin $/ 100 \mathrm{ml}$.). The serum protein and non-protein nitrogen levels were estimated by micro-Kjeldahl digestion followed by direct nesslerization as described by Hickmans (1948). Broadbent and Finch (data to be published) have compared the average results for serum protein concentrations obtained by this method with those obtained by a titration method and have found that they are lower by about $0.25 \mathrm{~g}$. protein $/ 100 \mathrm{ml}$. serum.

Subjects for the Investigation. During the period September, 1945, to October, 1947, 203 premature infants admitted to the City of Birmingham Premature Infant Unit (the Sorrento) or to the Birmingham Children's Hospital were included in the investigation. Fifty-five were omitted from the final analysis of the results for the following reasons:

General condition had deteriorated between the third and seventh day $\ldots$.. Infections contracted during the investigation Not been kept on the diet (usually to hasten discharge from hospital)

The remaining 148 infants received the following diets:

PERIOD I

High Protein (H.P.) Diets

Evaporated milk mixtures containing 'Ashe' casein hydrolysate..${ }^{\circ}$ Human milk mixtures containing "Ashe"; casein hydrolysate Low Protein (L.P.) Dirtets

Evaporated milk mixture control feed .. 1

PERIODS I AND II

Human milk (alone or complemented with control feed)

. 17

Period II

Higher Calorie and High Protein (H.C.P.) Diets Evaporated milk mixture containing ' Genatosan' casein hydrolysate ... . .

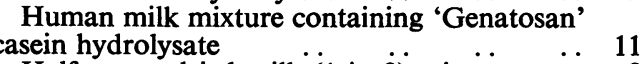
Half-cream dried milk $(1$ in 8$)$ mixture $\quad \begin{array}{lll}. & 3\end{array}$

Fourteen of the infants who received the high protein and low protein diets at the beginning of the first period were given considerably lower intakes of calories than the others, because the more dilute evaporated milk mixtures (Stages 1 and 2) were continued for a longer time. The results from this small series of infants receiving lower calorie diets have therefore been assessed separately. They will be referred to as the preliminary series observed during the first period.

\section{Results}

The effect of the diets shown in Tables 4 and 5 has been assessed by comparing the average weekly gain in weight and the serum protein and haemoglobin levels of the infants receiving them. The progress of the infants in each of the five weight groups has been considered separately. Twenty-six of the 148 infants have been excluded from this analysis because in some groups the number of infants receiving the same diets was too small to average. For instance, Group I included only ten babies, and therefore each of the diets was given to a few infants only. The average weight curves and the serum protein levels of the infants in Groups 2-5 seemed to show that the progress and nutrition of the smaller babies was more affected by diet than was that of the bigger infants. The individual weight curves of all the babies in Groups 1 and 2 have therefore been studied in detail.

Average Intake of Food. Table 7 shows the average amounts of food ingested by the infants in Groups 2-5 whose weekly weight gains have been included in the construction of the average weight curves. In estimating the intake of food by each infant allowances have not been made for the slight inevitable losses due to small amounts clinging to the bottles and teats or spilt on the bed linen. These have been estimated to be of the order of $5 \%$ (Gordon et al., 1940). If an infant vomited, however, an estimate of the amount was made and deducted from the intake for the day. It can be seen that an intake of 120 calories/ $\mathrm{kg}$./day was usually reached by the third week of life for the infants observed in the second part of the investigation, but not until the fourth week for those in the first part. The intake of calories was also higher during the second week of life for those in the second period. It is apparent that the average intakes of the infants observed in both periods later reached a somewhat higher level than would have been expected from the feeding schedules shown in Table 4. This was chiefly due to the fact that larger volumes of food than $3 \mathrm{oz}$./lb./day was given to many of the infants because they seemed hungry and were able to tolerate more food.

Gain in Weight. A curve representing the gain in weight of the foetus during the last three months of gestation has been drawn using the figures for the weight of the foetus at different ages given by Huggett (1946). This curve has been made the basis of comparison for the weight curves of premature infants at corresponding weeks of gestation. Other authors (Streeter, 1920; Crosse, 1945; Anderson, 1946) have presented different figures for the weight of the foetus and if the average of the available data had been used, the curve would have been slightly higher but of similar shape to the one which is shown in the diagrams. 


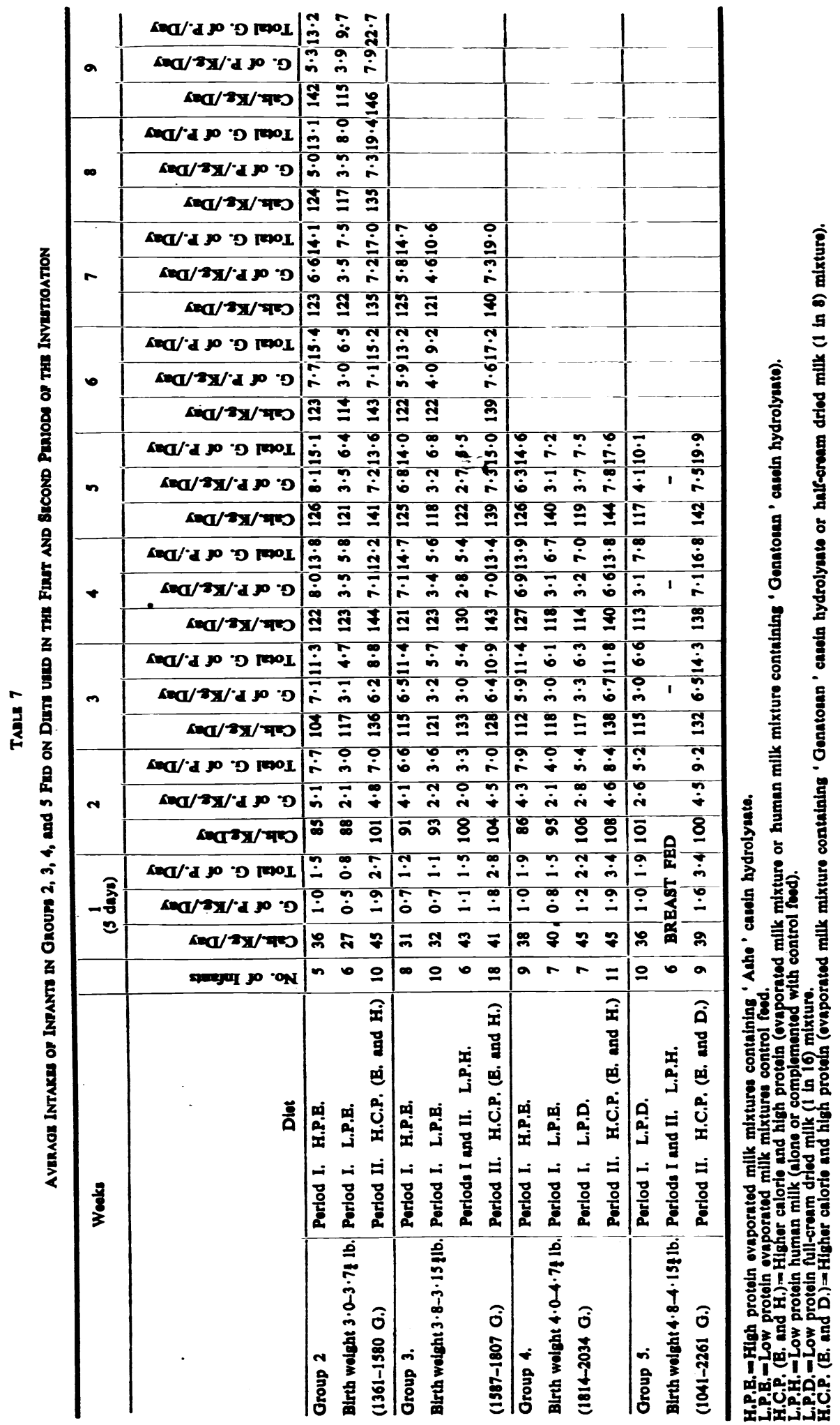


Average Weight Curves. The average weight curves of the infants in Groups 2-5, who received the diets in the amounts recorded in Table 7, are shown in Fig. 1.

Groups 3-5 (BIRTH WeIght $3 \frac{1}{2}-5$ lb.). The average curves for the larger infants will be described first, since they appear to be similar to each other for all the diets which were used (Fig. 1b, 1c, 1d). After an initial loss of weight during the first week and slow gains during the second and third weeks, the weekly rate increased, becoming equal to the amount which is gained by the foetus in utero. This is well shown by the slope of the weight curves which is parallel to that of the 'standard' growth curve. It may be concluded therefore that the diets used in both parts of this investigation provided sufficient food to enable the bigger infants to grow at the 'normal' rate for their age of gestation.

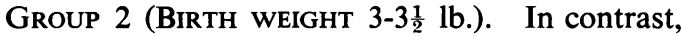
the average weight curves of the smaller infants (Fig. 1a) appear to have varied according to the diets which they were receiving. Thus the infants who were receiving higher intakes of calories in diets containing 'Genatosan' casein hydrolysate (H.C.P.) during the second part of the investigation, gained more weight between the ages of four and eight weeks than did those receiving either the high protein diet containing 'Ashe' casein hydrolysate (H.P.) or the low protein control diets (L.P.) during the first part of the investigation. Since their weight curve is parallel to the standard, it is evident that the faster rate of gain achieved by the infants in the second period of the investigation resembles that of the foetus in utero and that of all the bigger infants (Figs. 1b,1c, and $1 d$ ). The slower rate of gain by the infants in the first period may therefore be regarded as unsatisfactory and probably due to insufficient food.

Individual Weight Curves. Since the smaller (Group 2) infants showed differences in weight gain which might be attributed to the diets which they were receiving (a finding which is in keeping with the observations made by Jorpes et al. (1946) and by Gordon et al. (1947)), the gain in weight of the individual babies in this weight group and in Group 1 have been studied and their weight curves are shown in Figs. 2 and 3. Figs. $2 a, 2 b, 2 c$ show the individual, and Fig. $2 d$ the average (repeated from Fig. 1a) weight curves of the infants in Group 2. Again, it can be seen that weight was gained more uniformly and often at a higher rate by the infants who were receiving the higher calorie and high protein (H.C.P.) diet of the second period (Fig. 2c) than by those who were receiving either of the diets (high protein or low protein control) of the first period (Figs. $2 a$ and $2 b$ respectively). Thus the average weight curves (Fig. $2 d$ ) are representative of the progress of most of the individuals.

For comparison, the curves of the six infants in this weight group who received the lower calorie intakes (three high and three low protein control diets) of the preliminary series have been graphed and they are shown as dotted lines in Figs. $2 a$ and $2 b$. Table 8 shows the average daily intakes of these six babies during the early weeks of life, and they are seen to be much lower than the intakes (Table 7)

TABLE 8

Average Intakes of Six Infants in Group 2 on Low Calorie (Stage 2) Feeds

\begin{tabular}{|c|c|c|c|c|c|c|}
\hline \multirow[b]{2}{*}{ Week } & \multicolumn{3}{|c|}{$\begin{array}{l}\text { High Protein Diet } \\
\text { (3 Infants) }\end{array}$} & \multicolumn{3}{|c|}{$\begin{array}{l}\text { Low Protein Diet } \\
\text { (3 Infants) }\end{array}$} \\
\hline & 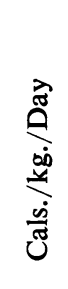 & 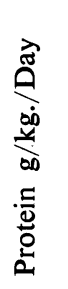 & 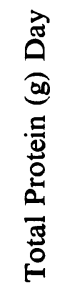 & 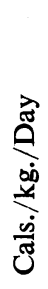 & 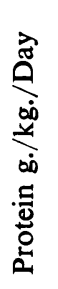 & 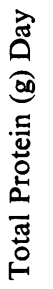 \\
\hline $\begin{array}{l}1 \\
2 \\
3 \\
4 \\
5 \\
6 \\
7\end{array}$ & $\begin{array}{r}34 \\
81 \\
103 \\
86 \\
89 \\
103 \\
112\end{array}$ & $\begin{array}{l}0 \cdot 7 \\
3 \cdot 7 \\
6 \cdot 1 \\
6 \cdot 2 \\
6 \cdot 7 \\
7 \cdot 4 \\
4 \cdot 4\end{array}$ & $\begin{array}{r}0 \cdot 9 \\
4 \cdot 7 \\
8 \cdot 5 \\
9 \cdot 6 \\
10 \cdot 8 \\
12.9 \\
8 \cdot 2\end{array}$ & $\begin{array}{l}34 \\
58 \\
89 \\
90 \\
87 \\
90 \\
98\end{array}$ & $\begin{array}{l}0 \cdot 6 \\
1 \cdot 6 \\
1 \cdot 7 \\
2 \cdot 2 \\
2 \cdot 2 \\
2 \cdot 2 \\
2 \cdot 3\end{array}$ & $\begin{array}{l}0 \cdot 8 \\
2 \cdot 0 \\
2 \cdot 6 \\
3 \cdot 0 \\
3 \cdot 2 \\
3 \cdot 5 \\
3 \cdot 9\end{array}$ \\
\hline
\end{tabular}

of the other infants in Group 2. The weight curves of the infants who were receiving the lower calorie and high protein intakes are seen to lie within the same range as those of the infants who received a higher intake of calories during the first period (Fig. 2a), but the infants who were receiving the lower calorie and low protein intakes are seen to have gained at a slower rate (Fig. 2b). The low protein control diet used for the preliminary series in the first period supplied an average of only 90 calories and $2 \cdot 2 \mathrm{~g}$. protein $/ \mathrm{kg}$./day by the sixth week (Table 8), so that the slow progress of the babies who were receiving it is easily explained. It is interesting to note that those on a low calorie but higher protein intake were able to gain more rapidly.

Group 1 (BIRTH WEIGHT LESS THAN $3.0 \mathrm{lb}$.). A relationship between diet and weight gain is also apparent from the progress of the ten smaller (Group 1) infants. The group consisted of four infants with birth weights between 2 and $2 \frac{1}{2} \mathrm{lb}$., all of whom were observed in the first period, and of six infants with birth weights between $2 \frac{1}{2}$ and $3 \mathrm{lb}$., one of whom was observed during the first, and five in the second period. The weight curves are shown in Figs. $3 a$ and $3 b$. It can be seen at once from Fig. $3 a$ that none of the infants under $2 \mathrm{lb} .8 \mathrm{oz}$. gained weight at the standard rate during the early weeks of life. Yet in the series of Gordon et al. 

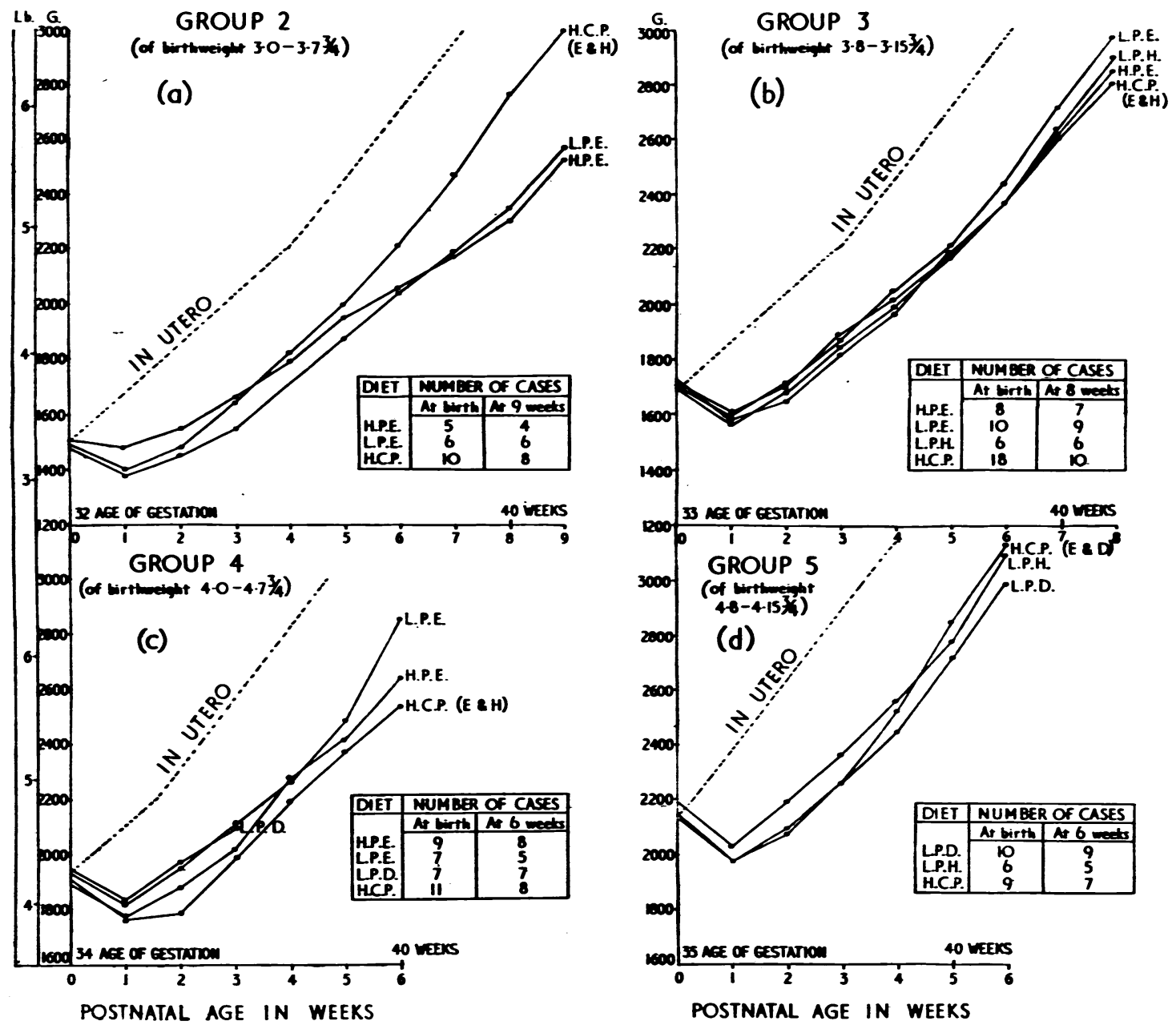

Fig. 1. - In each of the weight groups 2, 3, 4 and $5(1 a, 1 b, 1 c$ and $1 d$ respectively), the average weight curves of series of infants who received the different diets are shown for comparison with each other and with the curve of the foctus at the same age of gestation.

H.P.E. $=$ high protein
L.P.E. $=10$ protein control I Period I.
L.P.D. $=$ low protein control $\}$
L.P.H. $=$ low protein. Periods I and II.
H.C.P. $=$ higher calorie and high protein (Period II) 


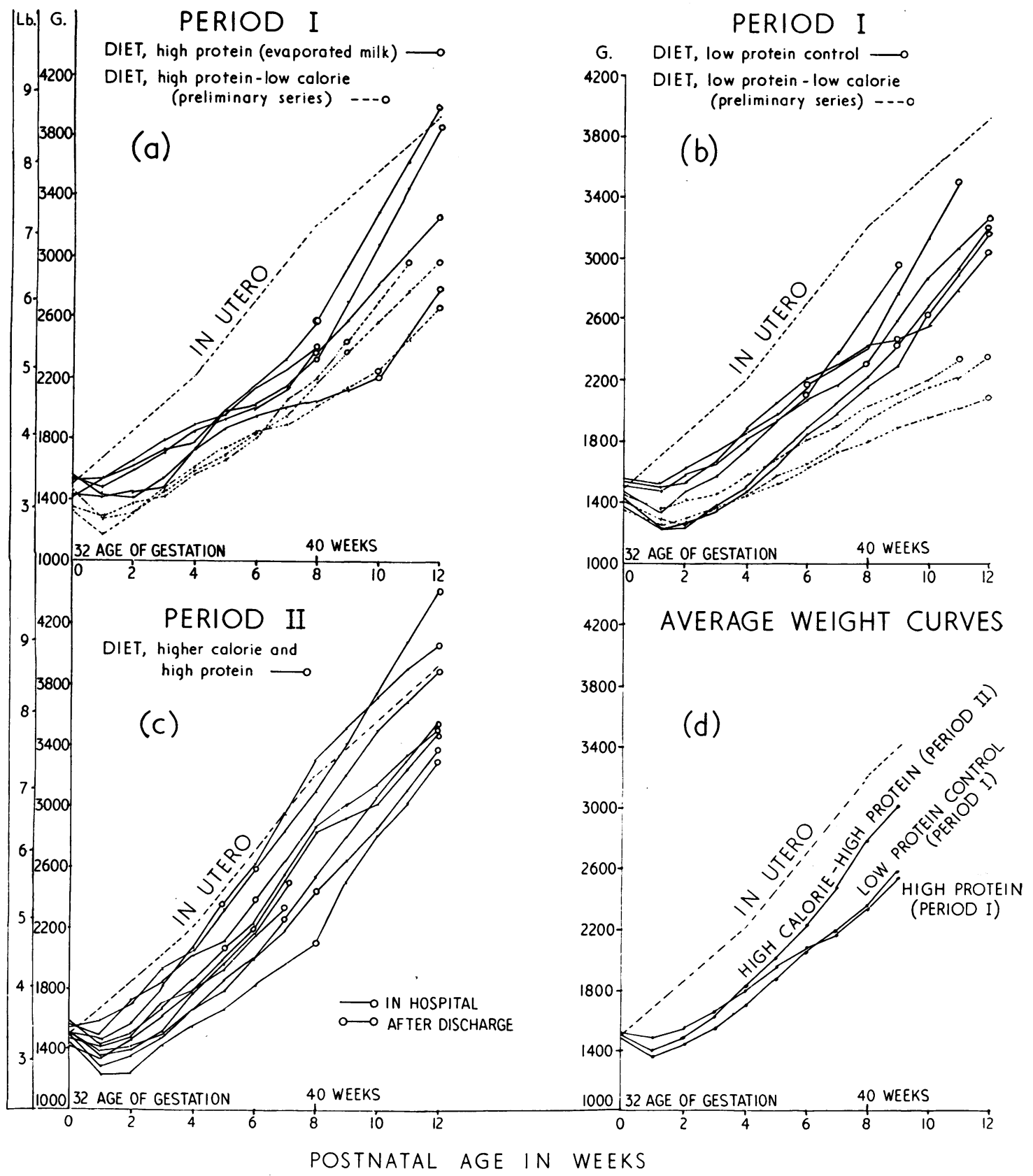

FIG. 2.-The individual $(2 a, 2 b, 2 c)$ and the average $(2 d)$ weight curves of the infants in Group 2 have been arranged according to the diets which they received. The individual curves of infants receiving the low calorie diets of the preliminary series have been graphed for comparison in $2 a$ and $2 b$, but they have been omitted in computing the average curves $(2 d)$. 
(1947) nine infants with similar birthweights who were fed on the half-skimmed milk mixture were able to do so, and their average weights at four and nine weeks of age have been graphed for comparison.

The diets given to the smaller infants in Group 1 (birth weight $2 \mathrm{lb}$. $0 \mathrm{oz}$. to $2 \mathrm{lb}$. $7 \frac{3}{4} \mathrm{oz}$.) in our investigation were as follows: one baby received human milk, one baby received human milk with the addition of 'Ashe ' casein hydrolysate, and two were fed on the lower calorie, low protein control diets of the preliminary series in the first period. None of the infants received as high an intake of calories during the second week as the subjects investigated by Gordon et al., and only A.H. had an intake which reached 120 cals./ kg./day at four weeks of age. This baby also had a higher protein intake than the others, a fact which will be referred to again when the serum protein levels are being discussed.

The bigger infants in Group I (birth weight $2 \mathrm{lb}$. $8 \mathrm{oz}$. to $2 \mathrm{lb} .15 \frac{3}{4} \mathrm{oz}$.) all received the higher calorie and high protein of the second period, with the exception of Baby G. who was given the low protein control diet of the first period. The weight curves depicted in Fig. $3 b$ show that this baby gained weight much more slowly than the rest, while the weight curves of the five infants who were observed in the second period are seen to be parallel with the standard curve from the second week of life onwards. It is of interest to note that two of these infants were receiving the evaporated milk, and three the human milk feeds (both of which contained 'Genatosan' casein hydrolysate), and that the rate of gain was similar whichever feed was being used. The two diets appear therefore to have been of equal value in promoting gain in weight, but this should not be taken to imply that human milk is without advantages for premature infants.

It seems evident from the present study of the progress of premature infants that the growth of the smaller, but not that of the bigger infants, was affected by the diets which were given. The larger babies were probably able to obtain sufficient food by 'demand' soon after birth and, because they were at a more advanced stage of development than the smaller ones, any minor deficiencies which may have been present in their diets did not cause retardation of their rate of growth. It is unfortunate that no babies weighing between 2 and $2 \frac{1}{2} \mathrm{lb}$. at birth were observed during the second period of the investigation and that therefore weight curves of very small infants receiving our 'optimum' higher

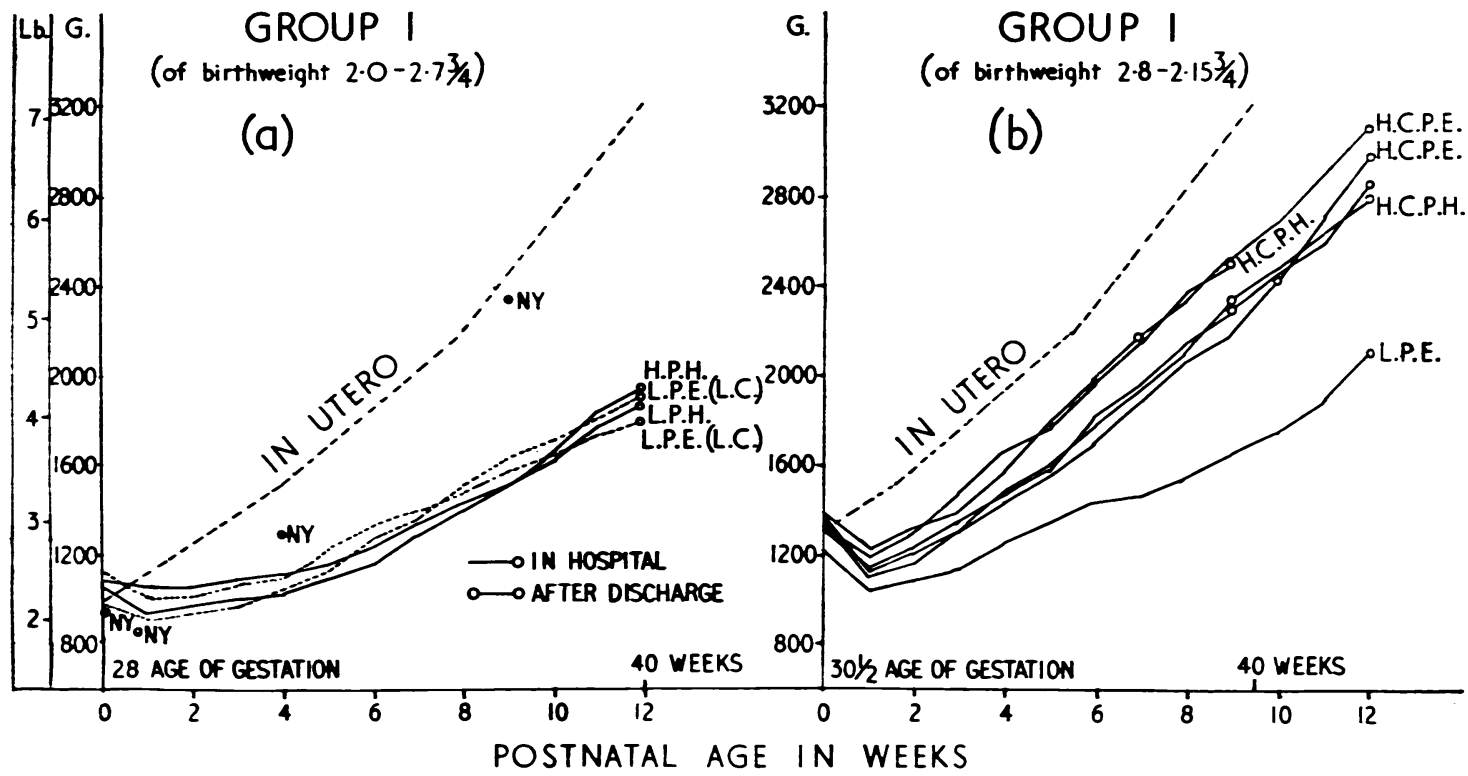

Fig. 3.-The infants in Group 1 have been sub-divided into two weight groups. The weight curves of individual infants receiving the different diets may be compared with each other and with the weight-curve of the foetus at the same age of gestation. The average weights of a group of nine infants in the same weight group who were observed by Gordon et al. (1947) are shown by the points marked $\odot$ N.Y. in $3 a$.

H.P.H. = high protein (Period I).

L.P.H. = low protein control (Periods I and II).

L.P.E. (L.C.) = low protein-low calorie (preliminary series, Period I).

H.C.P. (E. and H.) = higher calorie and high protein (Period II).

L.P.E. $=$ low protein control (Period I). 
calorie and high protein diet are not available for comparison with the progress made by the series of small premature infants (Gordon et al., 1947).

Serum Protein Levels. The serum protein levels of the infants observed in the second period have been analysed first, since these infants all received the same diet and samples of blood were obtained from them at more frequent intervals than from those observed during the first period of the investigation. The average results of this later period have then been used as standards with which to compare the levels obtained in the earlier period. Figs. 4, 5, and 6 show the scatter and the averages for the total serum protein, albumin, and globulin levels respectively, of infants weighing between 3 and $5 \mathrm{lb}$. at birth who were observed during the second period. A comparison of the average levels of the infants in these three weight groups with those of full-term infants (Poyner-Wall and Finch, data to be published) at similar ages after birth is shown in Figs. $4 d, 5 d$, and $6 d$. The scatter diagrams show that the range and distribution of the total serum protein levels are similar in all three weight groups of premature infants (Figs. $4 a, 4 b, 4 c$ ). The average levels are therefore approximately the samefrom week to week (Fig. 4d). Thus there is no apparent relationship between maturity (judged by birth weight) and the serum protein levels. Rimington and Bickford (1947) have shown that the serum protein levels in cord blood tend to increase with ' gestational' age and it seemed probable that the levels of premature infants would also be found to vary with their maturity at birth. The range for the birth weights of the infants in the present investigation may not have been wide enough for this relationship to be shown. Differences in birth weight between 3 and $4 \frac{1}{2} \mathrm{lb}$. represent only four weeks of 'gestational' age, and the estimation of age by birth weight can only be made approximately to within three weeks (Streeter, 1920). If results from a larger number of infants weighing less than 3 and more than $5 \mathrm{lb}$. at birth had been available for analysis a relationship between the serum protein levels and maturity at birth might have been apparent.

Fig. $4 d$ shows that the average serum protein levels for all three groups of premature infants were significantly lower than those of full-term infants during the first ten weeks of life. This difference was due to both the albumin and globulin fractions being low. Thus it can be seen from Figs. 5 and 6 that the range and distribution (Figs. 5 and $6 a, b, c$ ) and the average (Fig. 5 and $6 d$ ) for both the albumin and globulin levels of the premature infants in all three weight groups were similar to each other, but that they were all lower than those of the full-term infants in Poyner-Wall and Finch's series. The globulin levels were relatively lower as a percentage of the full-term infants' levels than the albumin levels. These low levels confirm the observations made by Darrow and Cary (1933) and by Rapoport, Rubin, and Chaffee (1943). Other previous observers (Utheim, 1920; Bridge, Cohen, and
McNair Scott, 1941; Hickmans, Finch, and Tonks, 1943) have found that the serum protein levels of premature infants are lower than those of full-term infants in the early weeks of life, but few details regarding the weight at birth and none about the diet of the infants are given in their reports. The premature infants who were the subjects in this part of our investigation were all receiving the high protein and relatively high calorie diet of the second period and therefore their low serum protein levels (compared with those of full-term infants) are unlikely to have been due to malnutrition. It has been noted that any infant who had a low level at two weeks of age usually maintained a low level for several weeks. Low serum protein levels have been found also in a proportion of infants born at term (Trevorrow et al., 1941; Poyner-Wall and Finch, data to be published) and it seems probable that they are due to a poor ability for generating plasma protein. Premature infants tend to have a poor response, but at three months of age their average serum protein levels are similar to those of full-term infants.

Fig. 7 shows the scatter of the total serum protein levels of the infants observed in the first period of this investigation compared with the average levels of those observed in the second period. The levels of the bigger infants (birth weight over $3 \frac{1}{2} \mathrm{lb}$.) shown in Figs. $7 c$ and $7 d$ will be described first (cf. weight curves in Fig. 1). The range and distribution of these serum protein levels is seen to be approximately the same for infants who were given the high protein and the low protein control diets, and the scatter lies equally above and below the average levels of the infants receiving the higher calorie and high protein diets of the second period. The levels of the infants who were breast-fed lay within the same range, but these have not been charted in order to simplify the diagrams. The albumin and globulin levels, estimated on the same samples as were used for total serum protein, were also found to be similar to those of the infants on the optimum diet. The findings show that the serum protein levels of the infants in these weight groups were unaffected by the differences in the diets used in the first and second periods of our investigation.

Figs. $7 a$ and $7 b$ show the levels of the infants in

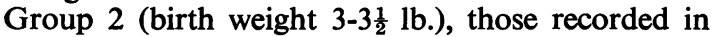
Fig. $7 b$ belonging to infants in the preliminary series who received lower calorie intakes (cf. weight curves in Fig. 2). Again a contrast with the findings from the bigger babies is shown, for the serum protein levels of the smaller (Group 2) babies appear to vary with the diets which were being given. Thus it can be seen in Fig. $7 a$ that the levels of the infants receiving the high protein diet, tend to be higher than those of babies on the low protein control diets, and that many of the low levels are far below the average for the infants receiving the higher calorie and high protein diets of the second period. Fig. $7 b$ shows that the serum protein levels of the infants who were receiving the lower calorie feeds 


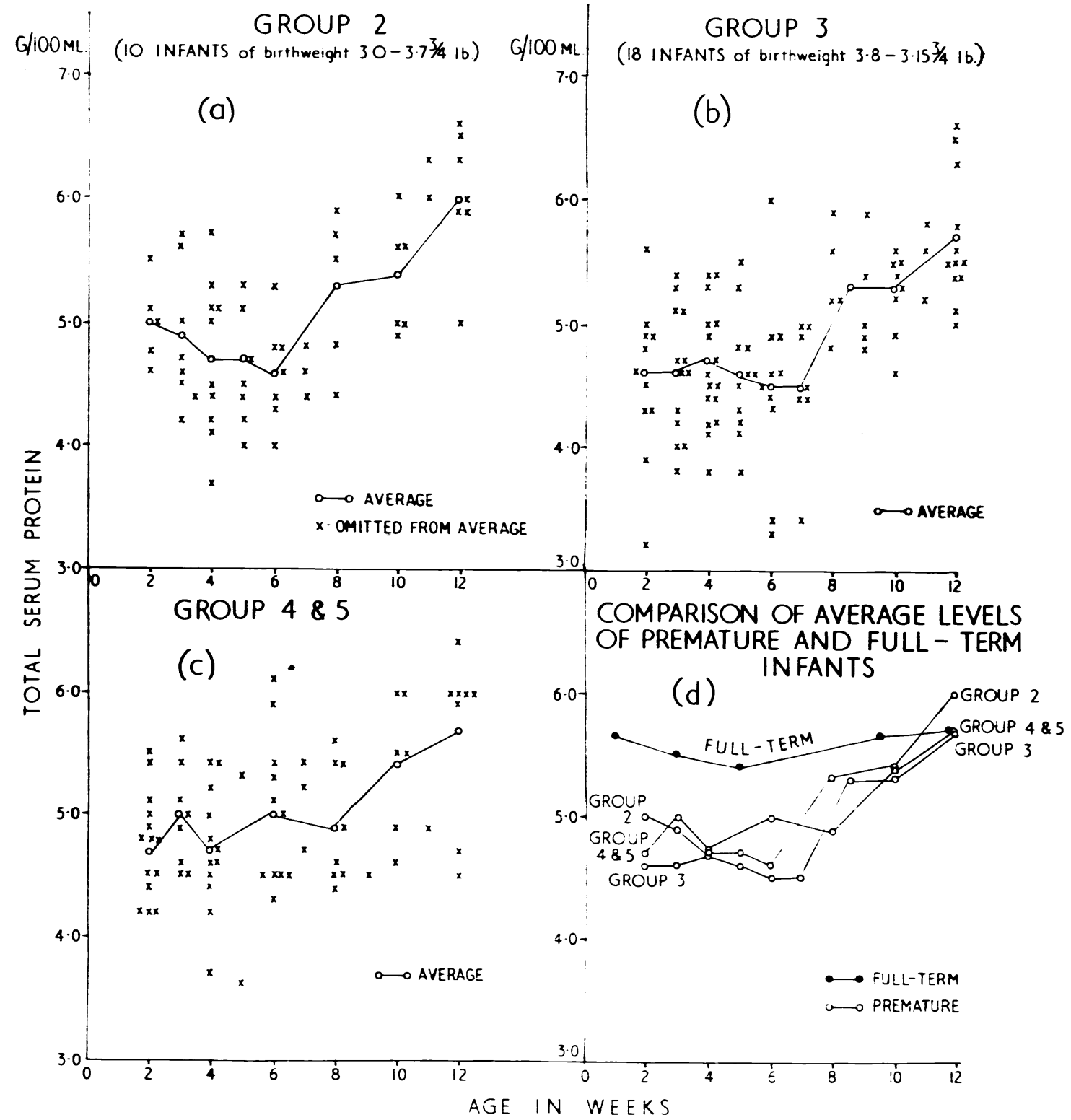

FIG. 4. $-4 a, 4 b$, and $4 c$ show the individual and the average total serum protein levels of the infants in the weight groups 2,3 , and $4+5$ respectively. The average levels for these groups are also shown in $4 d$ for comparison with each other and with the average levels for full-term infants. The optimum diet was the higher calorie and high protein diet of Period II. 


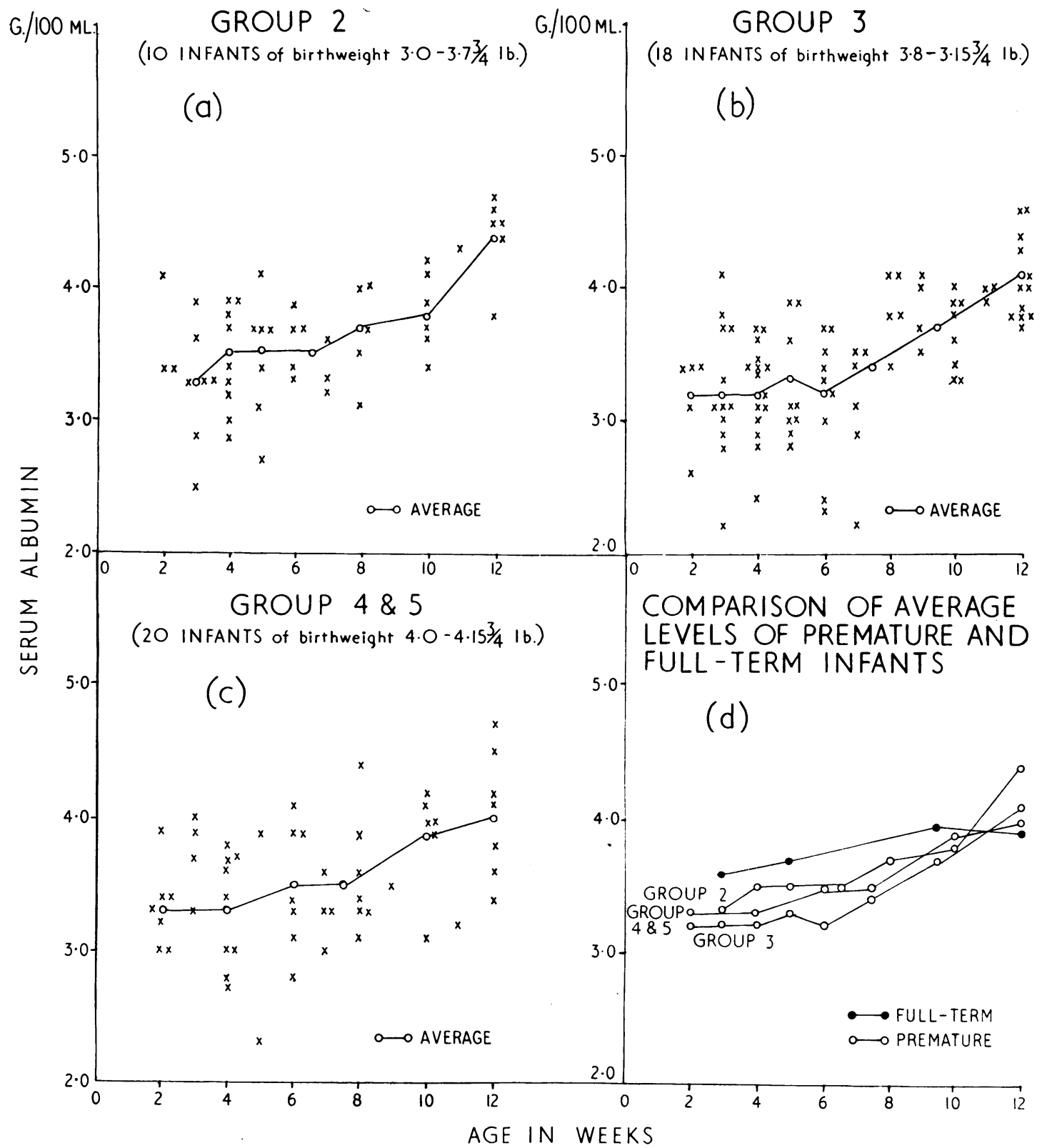

Fig. 5. $-5 a, 5 b$, and $5 c$ show the individual and the average albumin levels of the infants in the weight groups 2 , 3 , and $4+5$ respectively. The average levels for these groups are also shown in $5 d$ for comparison with each other and with the average levels for full-term infants. The optimum diet was the higher calorie and high protein diet of Period II. 
of the preliminary period (whether high or low in protein) were nearly all below the average levels of the second period. This finding suggests that both the low calorie diets were deficient, and that hypoproteinaemia, probably due to undernutrition, had occurred despite the relatively high protein intake of the infants receiving the low calorie high protein diet. It is interesting to note, however, that the weight curves of these infants were higher than those of the infants receiving the low protein diet (see Figs. $2 a$ and $2 b$ ). The albumin and globulin levels estimated on the same samples as were used for total serum protein show that the low total levels, which have just been described for some of the infants in Group 2 who were observed during the first period, were usually due to the albumin fractions being low. This finding lends support to the view that the hypoproteinaemia of these cases was due to nutritional deficiency. The results obtained from the few infants weighing less than $3 \mathrm{lb}$. at birth (Group 1) are in agreement. Thus all

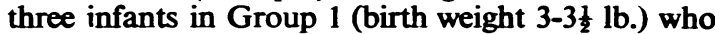
received the low protein diets had much lower serum protein levels during the early weeks of life than A.H., who received human milk with added casein hydrolysate (Ashe), and the one infant in Group 1 (birth weight $2 \frac{1}{2}-3 \mathrm{lb}$.) on the low protein control diet, had lower levels than the five on the higher calorie and high protein diet. Moreover, the average levels of these five infants, and A.H's levels, were as high as the average levels of the bigger babies and therefore may be regarded as indicating a good nutritional status.

Haemoglobin Levels. The haemoglobin levels of the premature infants observed in this investigation were analysed in the same way as their weight curves and serum protein levels, i.e. according to birth weight and to the diets which they received. The results show that the range and distribution of the haemoglobin levels of the infants in Groups
2-5 (excluding the infants in the preliminary series of the first period) were alike for the series of infants receiving each of the three diets shown in Table 7 . Since the levels appear to have been unaffected by diet, they have all been averaged together in each weight group and the findings are shown in Table 9. It can be seen that the average levels of the infants were alike in the four groups of babies whose birth weights ranged between 3 and $5 \mathrm{lb}$. All the levels of the infants in these weight groups have therefore been averaged together and the results are also shown in Table 9. A previous study of the haemoglobin levels of premature infants according to weight at birth has been made by Mackay (1935) and she also obtained similar levels in each weight group. Furthermore the curve described by the average levels of all the infants in Groups 2-5, is like the one recorded by Mackay for the haemoglobin levels of premature infants whose birth weights lay between 3 and $5 \mathrm{lb}$. Mackay used the Haldane method for estimating haemoglobin, the levels being matched against a standard by direct vision. In discussing her results she notes that the levels of the infants in her series were higher than those recorded by other observers and suggests that the incidence of anaemia in premature babies may partly depend upon the diets which they receive.

Like the serum protein levels, the haemoglobin levels of the infants in Groups 1 and 2 who were given poor diets tended to be low. Thus three ob the four infants in Group 1 who were given low protein diets were found to have haemoglobing levels of $60 \%$ at some time between the fourth and tenth week of life, whereas the levels of the six babies in the same weight group who were given high protein diets all remained above $65 \%$. Similarly, three of the six infants in Group 2 who received the low calorie diets of the preliminary series, had levels of $60 \%$ or lower, but among 21 in this weight group who received the higher intakes of the first

TABLE 9

The Average Haphoglobn Levels

\begin{tabular}{|c|c|c|c|c|c|c|c|c|c|c|c|c|c|c|c|c|c|c|c|c|c|c|c|}
\hline \multirow[t]{2}{*}{ WEEKS } & \multicolumn{3}{|c|}{2} & \multicolumn{2}{|c|}{3} & \multicolumn{2}{|c|}{4} & \multicolumn{2}{|c|}{5} & \multicolumn{2}{|c|}{6} & \multicolumn{2}{|c|}{7} & \multicolumn{2}{|c|}{8} & \multicolumn{2}{|c|}{9} & \multicolumn{2}{|c|}{10} & \multicolumn{2}{|c|}{11} & \multicolumn{2}{|c|}{12} \\
\hline & & 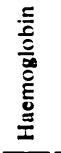 & 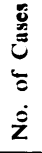 & 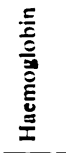 & $\begin{array}{l}0 \\
0 \\
0 \\
0 \\
0 \\
\dot{z}\end{array}$ & 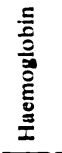 & $\begin{array}{l}0 \\
0 \\
0 \\
0 \\
0 \\
\dot{z}\end{array}$ & 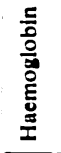 & 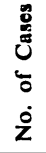 & 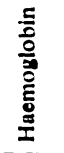 & 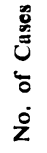 & $\begin{array}{l}\text { 틍 } \\
\text { 을 } \\
\text { 을 } \\
\text { 플 }\end{array}$ & 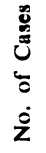 & $\begin{array}{l}\text { 들 } \\
\frac{0}{5} \\
\stackrel{0}{\Xi} \\
\stackrel{ }{0} \\
\text { I }\end{array}$ & 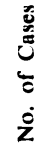 & 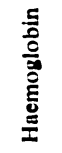 & 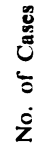 & 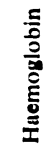 & 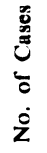 & 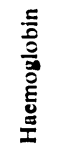 & 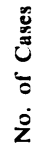 & $\begin{array}{l}\text { 등 } \\
\text { 음 } \\
\text { 음 } \\
\text { 음 }\end{array}$ & 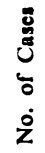 \\
\hline $\begin{array}{l}\text { Group } 2 \\
\text { Birth weight } 3 \cdot \ddot{0}-3 \cdot 7 \dot{\mathrm{lb}} \text {. }\end{array}$ & $\begin{array}{l}\cdots \\
\cdots\end{array}$ & 140 & 11 & 120 & 8 & 111 & 17 & 93 & 8 & 86 & 14 & 75 & 4 & 72 & 18 & 78 & 1 & 71 & 8 & 73 & 1 & 77 & 13 \\
\hline $\begin{array}{l}\text { Group } 3 \\
\text { Birth weight } 3 \cdot \ddot{8}-3 \cdot 15 \ddot{l} \text { b. }\end{array}$ & $\cdots$ & 131 & 22 & 120 & 18 & 106 & 28 & 87 & 10 & 80 & 22 & 79 & 8 & 76 & 12 & 70 & 8 & 74 & 12 & 76 & 6 & 77 & 19 \\
\hline $\begin{array}{l}\text { Group } 4 \\
\text { Birth weight } 4 \cdot \ddot{0}-4 \cdot 7 \dot{\mathrm{lb}} \text {. }\end{array}$ & $\begin{array}{l}\cdots \\
\cdots\end{array}$ & 126 & 22 & 117 & 11 & 103 & 24 & 83 & 3 & 77 & 13 & 95 & 5 & 72 & 14 & 75 & 4 & 73 & 6 & 84 & 4 & 72 & 10 \\
\hline $\begin{array}{l}\text { Group } 5 \\
\text { Birth weight } 4 \cdot \dot{8}-4 \cdot 15 \dot{i} \text { lb. }\end{array}$ & $\begin{array}{l}\cdots \\
\cdots\end{array}$ & 134 & 15 & 128 & 5 & 111 & 5 & & & 82 & 8 & 83 & 3 & 88 & 6 & 67 & 3 & 79 & 4 & 81 & 3 & 83 & 5 \\
\hline Groups 2-5 & . & 132 & 70 & 120 & 42 & 106 & 74 & 89 & 21 & 81 & 57 & 83 & 20 & 75 & 44 & 71 & 16 & 73 & 30 & 79 & 14 & 76 & 47 \\
\hline Standard Deviation & . & \pm 15 & & \pm 14 & & \pm 19 & & \pm 21 & & \pm 12 & & $\doteq 12$ & & \pm 12 & & $\doteq 10$ & & \pm 8 & & \pm 10 & & \pm 11 & \\
\hline
\end{tabular}


period and the optimum diet of the second period, 19 maintained levels over $65 \%$ and only one baby's level fell to $60 \%$ and one other to $62 \%$. It seems evident that nutritional deficiency increases the incidence of low levels amongst babies with birth weights below $3 \frac{1}{2} \mathrm{lb}$. Accordingly haemoglobin levels which fall below $65 \%$ during the first three months of life should probably be regarded as a sign of anaemia in premature infants, and the cause should be sought. Although a relationship between defects in the diet and low serum protein and haemoglobin levels has been found in our investigation, a much larger series of infants in the lower weight groups must be examined in order to establish the validity of these observations.

Non-Protein Nitrogen Levels. The samples of serum used for the estimation of protein were analysed for non-protein as well as for total nitrogen, and a comparison has been made between the non-protein nitrogen levels of the infants receiving the different diets which were used in the investigation. Only the levels of the infants in Groups 2, 3, and 4 who were between the ages of one and four weeks have been included. The levels from the babies in the three weight groups have been averaged together for each of the diets and Table 10

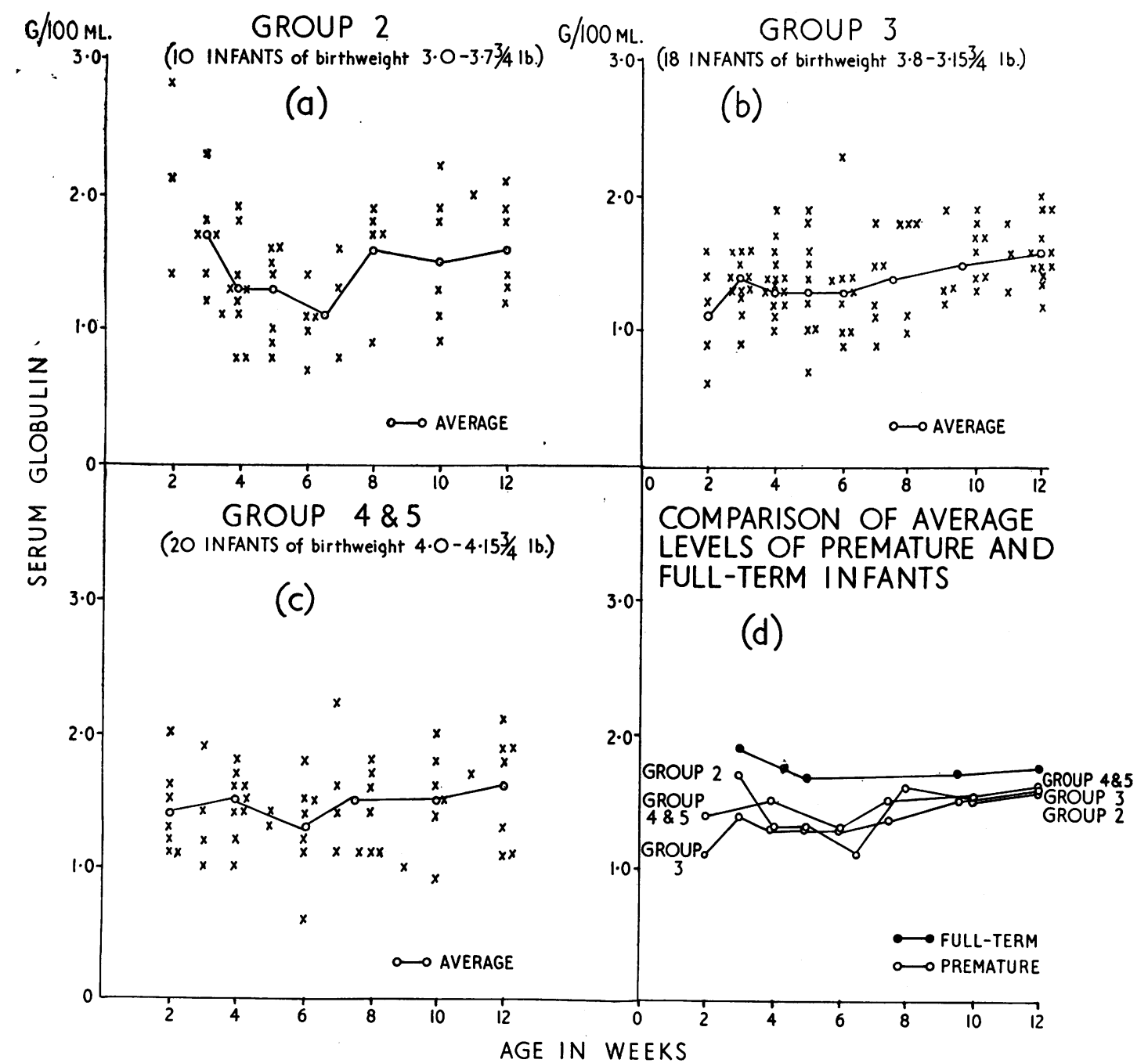

FIG. 6. $-6 a, 6 b$, and $6 c$ show the individual and the average globulin levels of the infants in the weight groups 2,3 , and $4+5$ respectively. The average levels for these groups are also shown in $6 d$ for comparison with each other and with the average levels for full-term infants. The optimum diet was the higher calorie and high protein diet of Period II. 
TABLE 10

NON-PROTEIN NITROGEN LEVELS

\begin{tabular}{|c|c|c|c|}
\hline $\begin{array}{l}\text { No. of } \\
\text { Levels }\end{array}$ & Diet & $\begin{array}{l}\text { Average Level } \\
\text { (mg. } 100 \mathrm{ml} .)\end{array}$ & $\begin{array}{c}\text { Range } \\
\text { (mg./ } 100 \mathrm{ml} \text {.) }\end{array}$ \\
\hline 29 & $\begin{array}{l}\text { High protein } \\
\text { of first period }\end{array}$ & 39 & $11-57$ \\
\hline 44 & $\begin{array}{l}\text { Low protein } \\
\text { control of first } \\
\text { period }\end{array}$ & 28 & $16-57$ \\
\hline 66 & $\begin{array}{l}\text { Higher calorie, } \\
\text { high protein of } \\
\text { second period }\end{array}$ & 27 & $11-41$ \\
\hline
\end{tabular}

shows the results. It can be seen that the average non-protein nitrogen level of the infants receiving the higher calorie, high protein diet of the second period was similar to that of the babies receiving the low protein control feed of the first period, but that it was lower than that of the babies on the high protein feed of the first period. This finding suggests that there may have been a protein-sparing effect from the higher calorie diet of the second period. Such an effect would have enabled the infants to utilize a greater amount of the protein in the diet of the second period than could be utilized from the equally high protein diet of the first period.

\section{Discussion}

The present investigation has yielded valuable information concerning the nutrition of premature infants. In agreement with previous investigators it has been found that these babies, after an initial loss of weight, may be expected to gain weight at the same rate as the foetus in utero, provided that they are given adequate diets. If, however, their diets are inadequate they may gain at a slower rate. Nutritional deficiency should therefore be suspected in babies who gain weight slowly

The results of this investigation do not allow a definition of the optimum diet for premature infants to be made. The average weight curves and the serum protein and haemoglobin levels of the infants observed in the second period seem to show, however, that their nutritional requirements were being met by the diets which they were receiving. The signs of under-nutrition, i.e. slower gain in weight and relative hypoproteinaemia and anaemia, which occurred in some of the infants of low birthweight (i.e. below $3 \frac{1}{2} \mathrm{lb}$.) observed in the first period, suggest that they were receiving diets which were insufficient. These diets were low in calories and/or protein compared with the theoretical requirements of premature infants. Although not apparent from the methods which have been used for assessing their progress, lesser degrees of under-nutrition may have occurred also in some of the bigger premature infants, who were given similar diets, but for shorter periods. In this connexion attention is drawn to the fact that gain in weight is not a direct index of 'normal' growth, and that the percentage composition of the body with regard to water, minerals, protein, and fat may not be the same in undernourished babies as it is in the well nourished foetus or young infant.

The slower rate at which weight was gained by the smaller (Group 2) infants who received the high protein diet of the first period compared with the progress of those who received the same protein but higher calorie intakes in the second period (Fig. 1a), must not be attributed without question to the difference in their intake of calories. It may have been due to the quality of the preparation ('Ashe') of casein hydrolysate which was used, e.g. its low calcium content might have reduced its growth-promoting properties. It should be noted that the serum protein levels of the infants who were receiving it were within the 'standard' range set by the results obtained from babies observed in the second period of the investigation. If knowledge were available concerning the relative biological efficiency of the two preparations of casein hydrolysate it might help us to interpret our results.

Casein hydrolysate has been found to be well tolerated by premature infants and it is therefore a valuable form of nitrogenous food with which to augment their protein intake. The effects of the diets used in our investigation and of those used by Gordon et al. (1947) may suggest that preparations of predigested protein, such as casein hydrolysate, have no advantage over the protein in half-skimmed milk mixtures. The alimentary tolerance of premature infants for whole milk protein might break down, however, if the conditions for nursing them were unlike those at the New York Hospital. There, the temperature and humidity in the premature infant units are accurately controlled and therefore the baby's intake of total fluid can be safely restricted to $150 \mathrm{ml}$. or less $/ \mathrm{kg}$./ day. Also, enough skilled nurses are available to give feeds by gavage at three-hourly intervals throughout the 24 hours. The amount of curd in the half-skimmed milk might not be so well tolerated if two-hourly feeds were being used, or if water were being given between feeds at times when the stomach was still partly filled.

It has been suggested that the low excretory function of the kidneys in premature infants restricts the amount of protein and minerals which they can tolerate. The studies of Gordon et al. (1947) seem 
GROUP 2

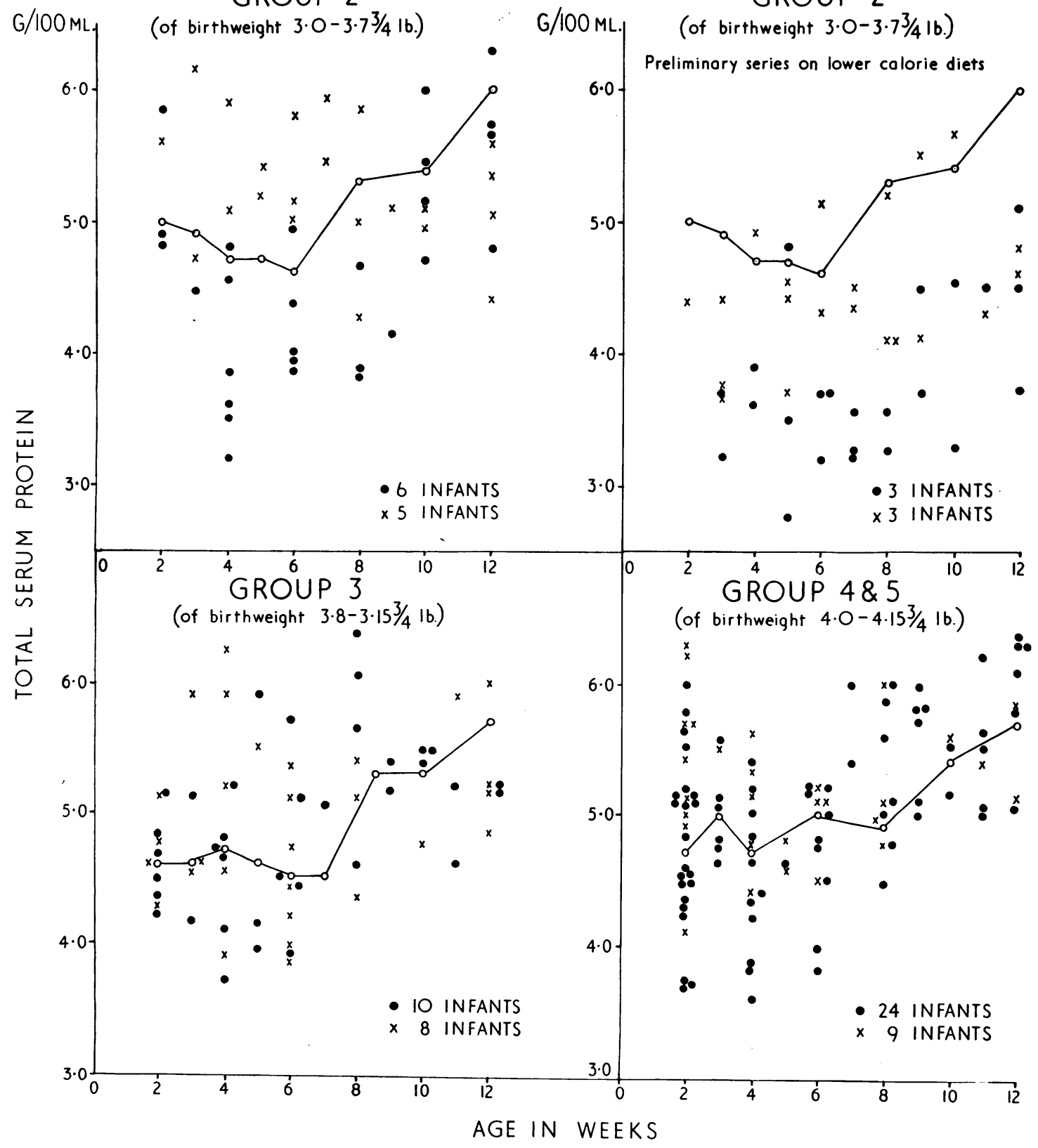

FIG. 7.-The total serum protein levels of the infants receiving the different diets of the first period may be compared with the average levels of the infants receiving the optimum higher calorie and high protein diets of the second period. The infants have been grouped according to their weight at birth as in the previous diagrams, but the levels of the infants in Group 2 who received the low calorie diets of the preliminary series have been recorded separately (Fig. $7 b$ ). The levels of the infants in the first period have been recorded for those receiving the high protein diets and for those receiving the low protein control diets, while the average levels of the infants receiving the optimum diet of the second period have been recorded $0-0$. 
to show that the excretory load from a diet containing twice as much protein as would be obtained from human milk lies well within the capacity of their kidneys. The range for the non-protein nitrogen levels of the infants in this investigation who were receiving $6.0 \mathrm{~g}$. or more of protein $/ \mathrm{kg}$./ day provide further evidence that this amount is not excessive.

Some paediatricians are sceptical about rapid early progress in premature infants and maintain that it is due to 'pushing' food; they believe that a slow gain in the early weeks should be regarded as satisfactory. According to our observations, infants who gain slowly may suffer from some degree of undernutrition at six to twelve weeks of age. Under such circumstances it would seem advisable to give high amounts of protein and minerals in order to make up for previous deficiencies.

Detailed information obtained from the follow-up care and observation of infants during the first year of life has not been presented in this paper. The later progress of the infants who weighed less than $2 \frac{1}{2} \mathrm{lb}$. at birth is of particular interest, however, in connexion with the findings relating to their early development. The four infants in this group, each of whom had gained weight very slowly during the first three months of life (Fig. 2a), all made very rapid progress at some period before reaching nine months of age, so that their weights then ranged between $14 \mathrm{lb} .12 \mathrm{oz}$, and $16 \mathrm{lb}$. $0 \mathrm{oz}$. This finding is somewhat surprising in the light of observations which have been made on the nutrition of young animals (Wallace, 1944; 1946). The degree of undernutrition which had occurred in these infants during their early weeks of life was evidently not severe enough to have restricted their development (as judged by weight gain) at later ages. Furthermore, clinical examination failed to show that these babies had been reduced to the plane of nutrition, described by McMeekan and Hammond (1940) in sheep, which causes permanent changes in the proportions of the body. The consequences of their undernutrition appear therefore to have been short-lived. Nevertheless, the premature infant who is undernourished must be at a disadvantage while this condition persists, the chief danger, as in all states of debility, being infection.

Although the serum protein levels of the premature infants receiving our optimum higher calorie and high protein diet were low compared with those of full-term infants, these levels are regarded as being 'physiological' for the early weeks of life. Both the albumin and the globulin levels were low, but the globulin values were relatively lower than the albumin. It would be interesting to study the gamma globulin fraction, and, if low levels were found, they might be related to the high death rate from infection amongst the prematurely born.

The present investigation has yielded observations which lead to tentative conclusions only, but an opportunity to continue these studies is not immediately available. It is hoped that they may provide a useful basis for further work and that they will stimulate a more complete investigation of the nutrition of small premature infants.

\section{Summary}

Two hundred and three premature infants were the subjects of an investigation which was planned in the first place as a trial of casein hydrolysate. Two preparations were used and were found to be well tolerated.

The relationship between the diet and the nutrition of the infants was studied by recording their gain in weight and by estimating their serum protein and haemoglobin levels during the early weeks of life.

The average rate of gain in weight (from the third week after birth) by premature infants receiving adequate diets has been found to be the same as that of the foetus in utero, and consequently it is proposed that this rate should be regarded as a 'standard' and slower gains as a sign of undernutrition. The average rate of gain in weight by the bigger infants (birth weight over $3 \frac{1}{2} \mathrm{lb}$.), did not vary with the diets which were used in this investigation and was equal to the 'standard.' In contrast, some of the smaller infants (birth weights under $3 \frac{1}{2} \mathrm{lb}$.), failed to gain at the 'standard' rate. They were receiving lower intakes of calories and/or protein than those of similar birth weight who gained at the 'standard' rate.

The average serum protein levels of the premature infants receiving the optimum diet of the second part of the investigation were found to be lower than those of full-term infants. This difference was due to both lower albumin and lower globulin fractions. Some of the infants with birth weights below $3 \frac{1}{2} \mathrm{lb}$. who failed to gain weight at the ' standard ' rate, showed even lower serum protein levels at four to eight weeks of age. These babies were receiving the poor diets to which reference has already been made. Low albumin levels were found in these cases which suggests that under-nutrition was the cause of the hypoproteinaemia.

Severe anaemia was rarely found to be present in the premature infants who were observed in this investigation. Levels below $60 \%$ were confined to the groups of infants of low birth weight, who received the relatively poor diets. 
Special attention to the nutritional requirements of infants who weigh less than $3 \frac{1}{2} \mathrm{lb}$. at birth is clearly indicated. Premature infants, including those of low birth weight, are able to assimilate diets containing at least 120 calories and $6 \cdot 0 \mathrm{~g}$. protein/ $\mathrm{kg}$./day during the early weeks of life. The minimum requirements of food for premature infants cannot be estimated from the knowledge which is at present available. They should therefore be given diets which contain enough protein and minerals to exceed their needs, so that a good nutritional status may be assured throughout the early months of life.

The authors wish to thank Professor Sir Leonard G. Parsons and Professor J. M. Smellie for their helpful criticism and advice, and the medical staff of the Children's Hospital and of the Sorrento Hospital, Birmingham, for allowing them to work in their wards.

W.F.Y., P.P.W. and H.C.H. each received a grant from the Medical Research Council, and W.F.Y. held the Caroline Harrold Research Fellowship, and I.B. the Cow and Gate Fellowship from the Department of Paediatrics and Institute of Child Health, of Birmingham University, during part of the time that these investigations were in progress. These awards are gratefully acknowledged. The Medical Research Council also provided the evaporated milk and the preparations of hydrolysed casein which were used.

The co-operation of the ward sisters has been invaluable, and Mr. J. G. Williamson, the photographer, has been of great assistance in preparing the diagrams.

\section{REFERENCES}

Albanese, A. A. (1947). 'Advances in Protein Chemistry.' New York Academic Press Inc., $3,227$.

Anderson, N. A. (1946). ' Clinical considerations of the Premature Infant.' Textbook of Paediatrics. Mitchell-Nelson, Philadelphia. W. B. Saunders Co.

Beach, E. F., Bernstein, S. S., and Macy, I. G. (1941). J. Pediat., 19, 190.

Blackfan, K. D., Diamond, L. K., Leister, C. M. (1944). 'Atlas of the Blood in Children.' New York; The Commonwealth Fund.

Bridge, E. M., Cohen, M. I., and McNair Scott, T. F. (1941). J. Pediat., 18, 709.

Broadbent, I., and Finch, E. (to be published).

Crosse, V. M. (1945). ' 'The Premature Baby.' London. J. \& A. Churchill, Ltd.
Crosse, V. M., and Hallum, J. L. (1947). J. R. sanit. Inst., 67, 409.

Daniels, A. L., and Hejinian, L. M. (1929). Amer. J. Dis. Child., 38, 499.

Darrow, D. C., and Cary, M. K. (1933). J. Pediat., 3, 573.

Gordon, H. H., Levine, S. Z., Daemer, W. C., and McNamara, H. (1940). Amer. J. Dis. Child., 59, 1185.

Gordon, H. H., Levine, S. Z., and McNamara, H. (1947). Amer. J. Dis. Child., 73, 442.

Gordon, H. H., Levine, S. Z., Wheatley, M. A., and Marples, E. (1937). Amer. J. Dis. Child., 54, 1030.

Hess, J. H., and Lundeen, E. C. (1941). 'The Premature Infant.' Philadelphia; J. P. Lippincott Co.

Hickmans, E. M., Finch, E., and Tonks, E. (1943). Arch. Dis. Childh., 18, 96.

Hickmans, E. M. (1948). Pediat. Internazionale, 1, 331.

Huggett, A. St. G. (1946). Brit. med. Bull., 4, 196.

Jeans, P. C., and Stearns, G. (1933). Amer. J. Dis. Child., 46, 69.

Jorpes, J. E., Magnusson, J. H., and Wretlind, A. (1946). Lancet, 2, 228.

Levine, S. Z., and Gordon, H. H. (1942). Amer. J. Dis. Child., 64, 274.

Mackay, H. M. M. (1935). Arch. Dis. Childh., 10, 195.

Macy, I. G., and Hunscher, H. A. (1934). Amer. J. Obstet. Gynec., 27, 878.

Magnusson, J. H., (1944). Nature, Lond., 154, 91. (1945). Acta paediatr., Stockh., 32, 599.

McMeekan, C. P., and Hammond, J. (1940). Emp. J. exp. Agric., 8, 6.

Miller, R. A. (1941). Arch. Dis. Childh., 16, 22.

Nelson, M. V. K. (1930). Amer. J. Dis. Child., 39, 76.

Parsons, L. G., and Hawksley, J. C. (1933). Arch. Dis. Childh., 8, 117.

Poyner-Wall, P., and Finch, E. (to be published). Arch. Dis. Childh.

Rapoport, M., Rubin, M. I., and Chaffee, D. (1943). J. clin. Invest., $22,487$.

Rimington, C., and Bickford, J. A. (1947). Lancet, $1,781$.

Streeter, G. L. (1920). Contr. Embryol. Carney Instn., $11,143$.

Trevorrow, V., Kaser, M., Patterson, J. P., and Hill, R. M. (1941). J. Lab. clin. Med., 27, 471.

Utheim, K. (1920). Amer. J. Dis. Child., 20, 366.

Wallace, L. R. (1944). Proc. Brit. Soc. Animal Prod., 58.

(1946). Ph.D.Thesis Cambridge-quoted Huggett (above).

Werner, B. (1948). Ann. Paediatr., Basel, 170, 8. 